\title{
The Implicated Neoliberal Subject in Thomas Pynchon's Bleeding Edge
}

\begin{abstract}
This article argues that in Bleeding Edge, Pynchon moves from an oppositional schema in which the world is divided into "elect" and "preterite" populations towards one that is concerned with implication and complicity. The article uses Michael Rothberg's The Implicated Subject (2019) as the basis for analysis, and notably his argument that to be implicated in wrongdoing often involves a kind of structural blindness towards suffering elsewhere. In the case of Bleeding Edge, the protagonist Maxine Tarnow is implicated in the violence committed in order to secure the hegemony of neoliberalism.

The article describes Maxine's gradual recognition of her own blindness, and hence of her implication in the harms perpetrated in the name of neoliberalism. It begins by noting that her experience of neoliberalism is one of process and of immaterial exchange. The second part of the article argues that the introduction of Nicholas Windust shows how neoliberalism may be an experience of rupture or trauma for those outside the developed world. Finally, with the 9/11 attacks on New York, the same violence rebounds against its source; they therefore act as the final stage in Maxine's increasing awareness of her own implication in neoliberal wrongs.
\end{abstract}

The epigraph to Bleeding Edge (2013) ${ }^{1}$ is a quotation from American crime writer

Donald E. Westlake: "New York as a character in a mystery would not be the detective, would not be the murderer. It would be the enigmatic suspect who knows the real story but isn't going to tell it." This signposts two key features of the novel. The first is the existence of an intermediate and slippery subject position, neither perpetrator, seeker of justice, nor victim. The second is the elusiveness of a narrative by which the nature of the crime in question and the identity of the criminal may be identified.

Bleeding Edge follows the rest of Pynchon's body of work in that it presents the

\footnotetext{
1 Thomas Pynchon, Bleeding Edge (London: Vintage, 2014). Page references are given parenthetically in the text.
} 
continuing advance of capitalism as a meta-crime that in turn produces further harms. However, the two formal aspects of Bleeding Edge noted above work together to create a shift in the affective politics of Pynchon's work. His novels are often read as operating on the basis of a division between the "elect" and the "preterite," The use of these terms, which originate in Calvinist theology and have frequently been linked to Pynchon's own family's Puritan roots, is nicely described in Rob Wilson's discussion of Inherent Vice (2009) as the tracing of a "centuries-long battle for the soul of America between what he calls the non-flatland Preterite (surfers, dopers, fun seekers, rockers, hippie riffraff, drifters, seekers, Indians, the poor multitudes, restless homemakers in little bars) versus the 'straight world' Elect (land developers, bankers, tax-dodging dentists, big shots, police within police, loan sharks, or worse."2 Pynchon's broad conception of history, then, is one in which, as Kathryn Hume argues, "a small group ... exercises power over a widely dispersed, much larger group of people who can find no effective way to fight back or gain freedom."3 Brian McHale suggests, through his reading of Gravity's Rainbow (1973), that the complexity of its plot invites paranoid readings that seek to decode and connect esoteric clues, thus aligning the reader with the preterite. ${ }^{4}$ Ali Chetwynd extends McHale's argument about paranoid reading through Pynchon's oeuvre up to Against the Day (2006), arguing that despair in the face of conspiracy "creates an adversarial

\footnotetext{
2 Rob Wilson, "On the Pacific Edge of Catastrophe; or, Redemption: California Dreaming in Thomas Pynchon's Inherent Vice," Boundary 2, 37.2 (2010) p.217-218.

3 Kathryn Hume, "Mason \& Dixon," in Inger H. Dalsgaard, Luc Herman and Brian McHale, eds., The Cambridge Companion to Thomas Pynchon (Cambridge: Cambridge University Press, 2011), 59-70, 64; see also Hanjo Berressem, "Coda: How to Read Pynchon," in Inger H. Dalsgaard, Luc Herman and Brian McHale, eds., The Cambridge Companion to Thomas Pynchon (Cambridge: Cambridge University Press, 2011), 168-188, and Amy Elias, "Paranoia," in Inger H. Dalsgaard, Luc Herman and Brian McHale, eds., The Cambridge Companion to Thomas Pynchon (Cambridge: Cambridge University Press, 2011), 121-135, 134: "History for Pynchon is a plot orchestrated by power. But this history is in dialectical relation with a 'history from below,' the unrecorded, accumulated force of preterite, everyday life."

${ }^{4}$ Brian McHale, Constructing Postmodernism (London and New York: Routledge, 1992), 88, $112 .$.
} 
'we' or 'us' in which those of Pynchon's readers who agree with his diagnosis that the good possibilities are gone can align themselves with each other and perhaps establish the kind of sociality that might viably defy the world they all agree is bad." 5

We generally concur that Pynchon's work up to Against the Day was based on a social and political division between the powerful and the disenfranchised - although it should also be stated that gray areas between the two camps exist, and are notably foregrounded in Vineland (1990), for example. However, a number of Pynchon scholars have noted a change of mode in Bleeding Edge, and to a lesser extent its predecessor Inherent Vice (2009), ${ }^{6}$ although the nature and consequences of this shift continue to be debated. ${ }^{7}$ Hanjo Berressem and Chetwynd both suggest that Bleeding Edge moves away from an oppositional schema, with the former noting that "instead of assuming an anonymous 'They', one must realise that 'They' are in fact real people living nextdoor to us" and that this "they" is "part of this real-life landscape of injustice and greed", ${ }^{8}$ and the latter contending that "Bleeding Edge's nonlinear pluralization of paranoid structure breaks with the basic premise that paranoia is a matter of "one" investigating subject "against" a consistent conspiracy." These observations are a useful starting point for discussing what Pynchon has departed

\footnotetext{
${ }^{5}$ Ali Chetwynd, "More metaphysician than politician: Pynchon, TINA, and the rhetorical economy of 'The World (This One)'," Textual Practice Volume 33, No 3 (February 2019), 451-471, 456-466.

6 Thomas Pynchon, Inherent Vice (London: Vintage, 2010).

${ }^{7}$ For example, Lee Konstantinou suggests that Pynchon has "slightly mellowed," while Hanjo Berressem argues that Bleeding Edge is "mostly dark, angry, and almost allegorical"; Kostas Kaltsas detects a new concern with family and community, while Chetwynd focuses on the way that "paranoia has become less a matter of conscious investigation than of passive reception." Lee Konstantinou, "The One Incorruptible Still Point: A Review of Thomas Pynchon's Bleeding Edge," Iowa Review Volume 43 No 3 (2013/14), 170-174, 171; Hanjo Berressem, "Economies of greed in 'late Pynchon': America and the logic of capital," Textual Practice Volume 33, No 3 (February 2019), 433-449, 434; Kostas Kaltsas, "Of 'Maidens' and Towers: Oedipa Maas, Maxine Tarnow, and the Possibility of Resistance" in Ali Chetwynd, Joanna Freer and Georgios Maragos, eds., Thomas Pynchon, Sex, and Gender (Athens GA: University of Georgia Press, 2018), 36-51, 44; Ali Chetwynd, "Pynchon after Paranoia," in Joanna Freer, ed., The New Pynchon Studies (Cambridge: Cambridge University Press, 2019), 33-52, 37.

${ }^{8}$ Berressem, "Economies of Greed," 437

${ }_{9}$ Chetwynd, "Pynchon after Paranoia," 41.
} 
from, but the question remains as to what Bleeding Edge instead moves towards. In this article, we argue that Pynchon has shifted into a mode that enables him to address complicity and implication both in the diegetic world of the novel through the representation of characters who participate in neoliberal practices, and also through the way the formal properties of the novel implicate the reader in the same system. More specifically, we argue that the novel conducts this examination by progressively revealing the nature of the characters' implication in the harms caused by neoliberalism.

The notion of implication enables an examination of behaviors that lie between perpetration and victimhood. The first attempt to fully theorize such a position is Michael Rothberg's The Implicated Subject (2019), in which he begins by noting the need for nuanced categories between these two poles, and in addition to the inadequately theorized "bystander" that occasionally appears in post-Holocaust writing. ${ }^{10}$ He defines implicated subjects as those who "contribute to, inhabit, inherit, or benefit from regimes of domination but do not originate or control such regimes." 11 One of his specific examples of implication is how wealthy consumers in the developed world are "participants in and beneficiaries of a system that generates

\footnotetext{
10 These three categories gained currency as a result of their use in Raul Hilberg's seminal discussion of the Holocaust and are a useful starting point, as is Primo Levi's elaboration of the "gray zone" in Auschwitz, but until recently there was little in the way of discussion of intermediate states between perpetration and victimhood. Recent useful interventions include Bruce Robbins' The Beneficiary, and an emerging body of work that addresses complicity (for example, Chiara Lepora and Robert E. Goodin's On Complicity and Compromise, and two recent collections of essays. Raul Hilberg, Perpetrators, Victims, Bystanders: The Jewish Catastrophe 1933-1945 (New York: Harper Collins, 1993); Primo Levi, The Drowned and the Saved, trans. Raymond Rosenthal (London: Abacus, 2013); Bruce Robbins, The Beneficiary (Durham, NC: Duke University Press, 2017); Chiara Lepora and Robert E. Goodin, On Complicity and Compromise (Oxford: Oxford University Press, 2015); see also Afxentis Afxentiou, Robin Dunford and Michael Neu, eds., Exploring Complicity: Concept, Cases and Critique (London: Rowman and Littlefield, 2016); Cornelia Wächter and Robert Wirth, eds., Complicity and the Politics of Representation (London: Rowman and Littlefield, 2019).

${ }_{11}$ Rothberg, The Implicated Subject: Beyond Victims and Perpetrators (Stanford, CA: Stanford University Press, 2019), 1.
} 
dispersed and unequal experiences of trauma and well-being simultaneously." 12 This is an apt description of many of the characters in Bleeding Edge, not least its protagonist Maxine Tarnow. We discuss her role as a decertified private investigator in detail below and argue that, as a consumer, a professional and a parent in Manhattan, she inhabits a position of implication, somewhere between the detective and perpetrator evoked in the novel's epigraph. In this way, the novel represents a move away from an oppositional politics that posits a division between "us" and "them", "elect" and "preterite", and instead suggests that contemporary neoliberalism has implicated much of the developed world in its wrongs.

Another way the novel explores implication is through the second aspect of its form suggested by the epigraph: that is, through the elusiveness of a coherent story. Maxine enters into a hermeneutic process of detection through which two apparently separate but intersecting stories emerge: these are, first, the fraud case involving hashslingerz and the young dotcom tycoon Gabriel Ice; and, second, the 9/11 terrorist attacks on New York. The first of these stories focuses on a world of immaterial labor and symbolic exchange, and represents neoliberalism as process, while the second introduces the sense that neoliberalism may produce material violence and rupture. Yet Maxine struggles to assemble a coherent narrative of recent events and thus fails to fully articulate the role that neoliberalism played in both the dotcom boom and crash, and in 9/11.

In Pynchon's earlier works, unknown and unknowable elements gestured towards conspiracies enacted by the rich and powerful outside the field of vision of the disenfranchised sections of the population whom they oppress. However, in Bleeding 
Edge, the lack of narrative mastery produced by this complexity serves a different purpose, with unknowability shown to be a symptom of the difficulty of recognizing one's own implication in a hegemonic system. As Rothberg notes, "socially constituted ignorance and denial are essential components of implication; as such, they are also potential starting points for those who want to transform implication and refigure it as the basis of a differentiated, long-distance solidarity", ${ }^{13}$ and in Bleeding Edge the beginnings of such a transformation occur. Instead of presenting a causal narrative of the relationship between neoliberalism and 9/11, it offers a story of Maxine's increasing awareness of her own implication in the economic system in which she participates. She begins the novel situated within neoliberalism as process, and is therefore largely unable to acknowledge her implication in neoliberal wrongs. However, the backstory of Nicholas Windust introduces the notion of violent rupture into the story, and with the 9/11 attacks, such a rupture directly impacts the United States. The attacks are represented as neoliberal violence rebounding on its source, and they serve as the final stage in Maxine's growing awareness of her implication in the same violence.

This article begins by addressing the relationship between the novel's characters and neoliberalism through the two stories noted above. The first section examines Maxine's implication in a system whose pernicious effects she fails to acknowledge, largely because she regards the system as a matter of process and of immaterial exchange. This section begins by discussing her role as a consumer, then argues that the novel embeds a history of the development of neoliberalism in her professional role, as a decertified private investigator.

13 Ibid., 200. 
The second section focuses on the notion of rupture. It argues that the violence towards which Maxine has hitherto remained blind begins to become visible through Windust's backstory, which includes violent interventions in the developing world, ostensibly in the name of democracy but actually as a means of securing the dominance of neoliberalism. The coming together of these two characters shows that what looks like continuity from one perspective may be an experience of trauma or rupture from another. In recognizing this disjuncture, Maxine begins to recognize her own implication in neoliberal violence.

In the final section of the article, we identify points of intersection between the material and immaterial spheres. In Multidirectional Memory (2009), ${ }^{14}$ Rothberg describes how a choc en retour - a backlash or reverse shock - can force an encounter between those in positions of comfort and security, and those whose suffering remains unseen to the former group. Through its representation of 9/11, Bleeding Edge suggests that the effects of neoliberalism may rebound, with material violence impinging on the comfortable world of immaterial exchange. In this way, the novel makes visible the ways ordinary people in the developed world are implicated in the suffering of those whose exploitation benefits them, but who for the most part remain out of sight. However, the encounter between Maxine and Windust's first wife Xiomara towards the end of the novel is a more optimistic - if still ambivalent - point of intersection between two different worlds. Xiomara bridges geographical spaces hitherto represented (in the novel's schema) as worlds apart. Her appearance, though, is not the same kind of violent rebound as $9 / 11$, but is one in which new forms of community, based on a recognition of implication, are proposed.

\footnotetext{
${ }^{14}$ Michael Rothberg, Multidirectional Memory: Remembering the Holocaust in the Age of Decolonization (Stanford, CA: Stanford UP, 2009).
} 


\section{Process}

One of Maxine's defining characteristics is the way she is simultaneously critical of neoliberal politics while participating in neoliberal practices, often with relish. She is a Clinton-era democrat, a "West-Side-liberal" (212) whose wry irony and sincerelyfelt social liberalism occasionally give way to "real-estate envy attack[s]." (4) Maxine has internalized consumption and competition to the extent that she embodies what Philip Mirowski calls "everyday neoliberalism", characterized by the "entrepreneurial self", by "promiscuous notions of identity", and where "competition is the primary virtue." 15

This internalized sense of competitiveness is generally evident in a world of symbolic and immaterial exchange. Tiina Käkelä identifies three "economic registers" in Bleeding Edge: the traditional economy as represented by property values, the "monetary financial economy" represented by her estranged husband Horst, a day trader, and "the new economy, or cognitive capitalism" represented by the villain, Gabriel Ice. ${ }^{16}$ While all three are present, Maxine and her friends are primarily concerned with the latter, and symbolic value carries the greatest weight in terms of their desires and decisions.

The strength with which everyday neoliberalism shapes Maxine's behavior is emphasized by the way that the novel details to the point of excess her brand obsessions and shopping addiction. A far-from-exhaustive list of brands coveted by Maxine and other characters whose stated political positions are in opposition to

\footnotetext{
15 Philip Mirowski, Never Let a Serious Crisis Go To Waste: How Neoliberalism Survived the Financial Meltdown (London: Verso, 2014), 92.

16 Tiina Käkelä, “"This land is my land, this land also is my land': real estate narratives in Pynchon's fiction”, Textual Practice Volume 33, No 3 (February 2019), 383-398, 393.
} 
neoliberalism (notably March Kelleher and Maxine's new-age guru Shawn) includes Chanel (28), Armani (30), TAG Heuer (31), Hermès (124), Dolce \& Gabbana (149), Mikimoto jewellery (150), Officina perfume (201), Coach (212), and Jimmy Choo (305); numerous well-known retailers, alcohol, furniture, and pop-cultural brands could be added here.

Jason Siegel connects the pervasion of neoliberal values to posthumanism, arguing that, in Bleeding Edge, "mind and body are inextricably interconnected and ... the individual consciousness cannot be separated from the environment it inhabits." 17 He also argues that, in contrast to other theorists (Donna Haraway, for example), Pynchon is less optimistic about the potential of a posthuman world, and that in Bleeding Edge the individual is "subject to an increased level of surveillance, manipulation, and exploitation." 18 While we agree with much of Siegel's argument and return to it in our final section here - we also suggest that his claim that the novel represents humans as "programmable objects" understates the role of desire in implication.

A good example of the way that the neoliberal economy creates the desires that then impel individuals to act in ways that perpetuate the system is when, early in the novel, Maxine watches in horror as her sons play a video game that involves exterminating "quality of life" criminals on the streets of New York, but soon finds herself drawn into participating, admitting that it is "sort of fun." (35) A more complex exploration of the same tendencies occurs during one of several of Maxine's trips to Saks on Fifth Avenue. Walking intuitively toward the famous retailer, Maxine imagines the possibility of seeing the diamond setting she has been "looking for her

\footnotetext{
17 Jason Siegel, "Meatspace is Cyberspace: The Pynchonian Posthuman in Bleeding Edge," Orbit: A Journal of American Literature Volume 4, No 2 (June 2016), 1-27, 3.

18 Siegel, "Meatspace is Cyberspace," 7.
} 
whole life." (285) Moreover, she is electrified by the feeling that "nothing, nobody on this block is positioned where they are by accident, that saturating the space, invisible as the wavelengths that carry soap operas into the home, dramas of faceted intricacy are teeming all around.” (285) Maxine, then, is far from being an unreflective participant in neoliberal culture, and does not only enjoy in its material aspects, but also revels in these "teeming dramas" of transaction and consumption that have pervaded every aspect of her world. Implication is figured here as a network of vectors of competition and consumption into which individuals are impelled to enter, but that they also desire.

Moreover, if the diegetic representation of Maxine's conflicts and desires addresses her implicated nature, the formal properties of the novel work to align the reader with her perspective. A consistent characteristic of the use of free indirect discourse is Maxine's habit of self-questioning, which is frequently built into ostensibly third-person narration. The novel's opening sentences employ a structure that becomes typical, wherein apparently objective third-person narration slides into Maxine's interior voice as she questions her own actions:

It's the first day of Spring 2001, and Maxine Tarnow, though some still have her in their system as Loeffler, is walking her boys to school. Yes maybe they're past the age where they need an escort, maybe Maxine doesn't want to let go just yet, it's only a couple of blocks, it's her way to work, she enjoys it, so? (1)

As the novel progresses this device is used at moments when Maxine makes questionable decisions, and occurs several times when she is about to enter into, or is recalling, encounters with Windust (103, 244, 253-54, 258, 411). McHale's argument regarding paranoid reading implicitly aligns the reader with the preterite section of the 
population and, as such, "we see ourselves mirrored in Pynchon's characters"19 who are generally subject to oppression and "at whom menacing fingers are repeatedly pointed, towards whom ominous faces turn to gaze."20 Yet given Maxine's subject position, the use of free indirect discourse in Bleeding Edge means the reader is no longer placed in the position of the preterite, but is instead aligned with an implicated subject.

Maxine's personal traits of consumerism and competition represent one form of implication in neoliberalism, but another type of engagement with neoliberalism, and another history of its development, is more subtly present insofar as it is attached to her role as a private detective. Sean McCann links classic detective fiction of the late 1800 s and early 1900 s with the political liberalism of that period, the genre being "centrally concerned with a fundamental premise of liberal theory - the rule of law and with the tensions fundamental to democratic societies that constantly threw that principle into doubt." ${ }^{21}$ Classic detective fiction was conservative, broadly speaking, because "civil society produces a stable order that can survive violence and abuse," and the detective's job was to restore stability to this world. ${ }^{22}$

It can be argued that the politically liberal interpretative quest of the classic detective obscures the economic repercussions of the same system due to its focus on individual crimes and possessions. In contrast, the hard-boiled genre, upon which the characterization of Maxine obviously draws, is a response to a crumbling faith in that stable order, itself the product of free market economics. McCann notes that hardboiled detective fiction emerged from a belief that "the traditional mystery tale was a

\footnotetext{
19 McHale, Constructing Postmodernism, 113.

20 Ibid., 113.

21 Sean McCann, Gumshoe America: Hard Boiled Crime Fiction and the Rise and Fall of New Deal Liberalism (North Carolina: Duke UP, 2000), 6.

22 Ibid., 16.
} 
political myth, illegitimate because it no longer corresponded to the complex realities of an urban, industrial society." 23 Instead of the detective-protagonist performing a restorative function by re-establishing social stability as premised on classic liberal theory, as social tensions mounted in the cities that were the product of this economic model - still within the period of Keynesian compromise and prior to the onset of neoliberalism proper - the detective came to occupy a liminal position, no longer fully aligned with the law or with the dominant ideology. For this reason, as Patricia Merivale notes, "the hard-boiled Private Eye often finds himself complicit in the corruption of the world to which he is supposed to bring lucidity and order, sometimes (usually unjustly) as a suspect himself.,"24

This complicity is evident in Pynchon's characterization of Maxine, whose role extends the critique advanced by the hard-boiled genre into the neoliberal era. Her fraud investigation agency - consisting only of her and an assistant - is called "Tail 'Em and Nail 'Em." We learn that "she once briefly considered adding 'and Jail 'Em,' but grasped soon enough how wishful, if not delusional, this would be.” (4) In other words, any expectation that the detective should restore justice to the world, either in the idealized form of the classic detective, or in the updated and battered form of the hard-boiled P.I., has long since vanished. Moreover, Maxine's decertification seems to have had no negative impact on her business and, rather, she feels that clients continue to approach her thanks to the way that it provides "a halo of faded morality, a reliable readiness to step outside the law and share the trade secrets of auditors and tax men." (17)

The 2001 of Bleeding Edge is a period where distinctions between guilt and

\footnotetext{
23 Ibid., 18.

24 Patricia Merivale, "Postmodern and Metaphysical Detection," in Charles Rzepka and Lee Horsley, eds., A Companion to Crime Fiction (Chichester: Wiley, 2010), 308-320, 311.
} 
innocence have to some extent collapsed. This is suggested by the generally amoral approach to life exhibited by many characters. Maxine even notes that, because of the introduction of computerized payrolls, "sometimes the distinction between hustling and being hustled broke down." (71) For this reason, Maxine's professional conduct invites us to consider her as what Rothberg calls a "perpetuator" because her actions contribute to, rather than rectify, a morally bankrupt system that has come unmoored from the principles that once underpinned liberalism - although the extent to which she knowingly contributes to this malaise is debatable. ${ }^{25}$ On numerous occasions, the novel shows Maxine to be complicit with a bureaucratic and economic system from which morality and justice have been evacuated. For example, she describes how what she once regarded as the "no-brainer choice between friendship and super-picky guideline adherence" eventually led to her becoming decertified (18). Later, she evokes a moral gray area when she refers to "the ancient CFE distinction between being complicit and merely attending to phone calls that should probably be answered"; on this occasion, she answers Gabriel Ice's call which ultimately furthers her involvement with Windust (136).

The situation is such that Maxine is far from bringing "lucidity and order" to the world, or to ensuring that justice underpinned by any ethical or collective framework is done. McCann notes that hard-boiled detective fiction emerged during periods when "the social forces prodding its development threatened to tear the very idea of a liberal society to pieces" 26 and that "the detective story both registered that threat and turned it into a manageable tale." ${ }^{27}$ In Bleeding Edge, Maxine fails to construct any such "manageable tale" from the clues she encounters regarding both

\footnotetext{
25 Rothberg, The Implicated Subject, 12.

26 Sean McCann, Gumshoe America, 6.

27 Ibid., 6.
} 
Gabriel Ice's affairs and 9/11. This lack of narrative mastery is part of the novel's project of representing neoliberalism as ungraspable, ${ }^{28}$ but is also partly the result of Maxine's failure to do her detective work with regard to the everyday effects of the system within which she works and thrives.

Kostas Kaltsas notes that Maxine is "self-aware regarding her roles; she is able to accept or reject them, often treating them ironically as set roles while performing their essence sincerely,"29 while Jennifer Backman suggests that she is able to switch between her role as a P.I. and the more stereotypically feminine modes that are sometimes expected of her. ${ }^{30}$ Yet the negative effect of this switching is a compartmentalization of the professional and the personal, which itself results in her inability to perform the kind of hermeneutic work on her own life that would allow her to detect her implication in neoliberalism.

This failure results in Maxine's blindness to the wider effects of her actions and habits. As noted above, the novel closely aligns the reader with Maxine's position through the use of free indirect discourse, but the issue of visibility is occasionally thematized explicitly. For example, a discussion of Rear Window segues into Maxine's recollections of watching the Deseret hotel through a pair of binoculars, in the days before she was able to gain entry: "at first Maxine found it romantic, all the mutually disconnected lives going on in parallel - later she came to take more of a

\footnotetext{
${ }^{28}$ Interestingly, one of the leading advocates of neoliberalism anticipated what we might expect to be a critique of it: as Quinn Slodobian notes, "Hayek began to realize in the 1930s that the dispersal of knowledge throughout an entire market economy was so complete that no individual could ever gain a functional overview of it. The shock of the 1930s brought with it the realization that the world economy was basically unknowable." Quinn Slobodian, Globalists: The End of Empire and the Birth of Neoliberalism (Cambridge, MA: Harvard University Press, 2018), 18.

${ }^{29}$ Kaltsas, "Of 'Maidens' and Towers: Oedipa Maas, Maxine Tarnow, and the Possibility of Resistance," 40, emphasis in original.

${ }^{30}$ Jennifer Backman, "From Hard Boiled to Over Easy: Reimagining the Noir Detective in Inherent Vice and Bleeding Edge", in Ali Chetwynd, Joanna Freer and Georgios Maragos, eds., Thomas Pynchon, Sex and Gender (Athens, GA: The University of Georgia Press, 2018), 19-35, 31
} 
what you'd call gothic approach." (28) What Bleeding Edge actually shows is that although lives may appear to be "mutually disconnected" within an atomized, latecapitalist city, they are all interrelated as part of a much larger system. As such, the "gothic approach" - unelaborated here, but seemingly one not far removed from McHale's paranoid reading in that it would seek to draw connections between complex and disparate elements - is actually a necessary approach for understanding one's implication in the neoliberal order.

While the passage above may be read allegorically, the novel is generally less explicit. Thre is ample evidence of the unequal relationship between the developed and developing worlds, but Maxine mostly fails to acknowledge it, regardingsuch references as incidental to her own story. For example, in her recollection of a cruise to the Haitian / Dominican border, the Perejil Massacre is mentioned in passing, but immediately after this reference she recalls how "things rapidly grow unfocussed" (16). This blindness as a feature of implication can also be seen in a passage that recalls - and is comparable to - Oedipa Maas's search for the Tristero in The Crying of Lot 49 (1966). ${ }^{31}$ Oedipa delves into the San Francisco underworld, following and attempting to decode symbols of an organization that stands in direct opposition to the hegemonic system. Superficially similar are Maxine's attempts to understand impenetrable graffiti about "cars for sale, announcements of love lost, found, or wished for, racial grievances, unreadable remarks in Cyrillic, Arabic, Chinese, a web of symbols, a travel brochure for night voyages Maxine has not yet thought about making." (85) The difference between Maxine's and Oedipa's efforts at interpretation is that the latter deals with an alternative network existing within Pynchon's fictional world, while the former presents messages that Maxine is unable to decode not

31 Thomas Pynchon, The Crying of Lot 49 (New York: Harper Perennial, 1999). 
because of a lack of esoteric knowledge, but due to her lack of genuine interest in and engagement with many of the cultures that comprise the population of New York, and whose products she consumes. As such, Maxine exhibits a kind of structural blindness that is both a symptom of and a contributing factor towards her implication in the neoliberal system.

For this reason, Maxine repeatedly fails to make these connections between the metropolitan core of New York and the periphery of the developing world. The geographical scope of the novel is notably limited, with Maxine only leaving the city twice, and remaining within New York State on both occasions. Where the developing world does come into view in the early parts of the novel, it does so in a way that neither makes visible the material reality of those who live there, nor the material effects of U.S. policy on those locations. Rather, the developing world enters New York as a range of commodities that are subject to consumption, often as food and drink. Over the course of the novel, Maxine eats at a "Ukrainian joint" (90), is introduced to the La Cibaeña Chinese-Dominican Café by Windust (103), goes to Chuy's hideaway, which serves rum and cokes and Presidente beers (163) and orders takeout from Ning Xia Happy Life, which offers dishes including "Long March Szechuan Muesli", "Magic Goji Longevity Shake", and "Gang of Four Vegetarian Combo", all of which are delivered to her by a Latino driver (214). Even when Maxine does physically travel to the developing world during a cruise to the border between Haiti and the Dominican Republic (prior to the timescale of the novel), she recalls how souvenir stands "quickly materialized, snack vendors selling yaniqueques and chimichurros, practitioners of voodoo Santería with spells for sale.” (16)

Jodi Melamed argues that neoliberalism "portrays an ethic of multiculturalism to be the spirit of neoliberalism and, conversely, posits neoliberal restructuring across 
the globe to be the key to a postracist world of freedom and opportunity." 32 In other words, neoliberalism disguises the adverse effects that it produces. Early in the novel, while the routine patterns of consumption made possible by globalization are evoked with a degree of cynicism, it is not directly linked to suffering and exploitation. For example, Maxine's hairdressers "are forever going off to Caribbean resorts for intensive tutorial workshops in color weaving" (49) and eastern philosophy is reduced to Buddhism-as-therapy by Maxine's guru, Shawn, whose first-hand experience of Asia appears to extend to little more than watching Scorsese's Kundun (30). At other times though, the narrative partially but inadequately acknowledges the inequality on which such commodification is predicated, including details that gesture towards potentially violent black market exchanges; though Maxine fails to fully acknowledge such possibilities. For example, a company called Packages Unlimited is guarded by “chained and padlocked doors ... flanked by Uzi-packing gorillas in uniform, who signed for mysterious shipments and deliveries" (4) while Vyrva McElmo's collection of Beanie Babies is secured via "a list of retailers on the East Side who get the critters shipped all but directly in from China by way of certain shadowy warehouses adjoining JFK." (39) In both cases, the illegality of these operations is presented as New York color rather than evidence of wrongdoing, and Maxine's failure to interrogate the mechanisms by which these exchanges function exemplifies Rothberg's argument that "the manifold indirect, structural, and collective forms of agency that enable injury, exploitation, and domination ... frequently remain in the shadows." 33

While the destructive effects of neoliberalism hover on the edge of her vision

\footnotetext{
32 Jodi Melamed, Represent and Destroy: Rationalizing Violence in the New Racial Capitalism (Minneapolis, MN: University of Minnesota Press, 2011), 138.

${ }^{33}$ Rothberg, The Implicated Subject, 1.
} 
for much of the novel, present but not fully acknowledged, it is with the appearance of Windust that that the relationship between the contemporary U.S. economic and political order, and violence perpetrated in the developing world, comes more squarely into view.

\section{Rupture}

The introduction of Windust punctures Maxine's conception of neoliberalism as being primarily a matter of immaterial and symbolic exchange in a number of important ways. At first, her conflicted attitude towards him mirrors and brings into sharper relief her conflicted attitude towards neoliberalism. However, as details of his background emerge, the fact that neoliberalism is experienced as rupture and as material violence by many in the developing world becomes visible. Moreover, the repeated references to Windust's "innocence" while detailing this history show how implication can overtake individuals, a transformation into complicity and perpetration outstripping any opportunity for reflection or for retreat from this path. Finally, as is the case with Maxine, a history of neoliberalism is embedded in Windust's professional role. This history connects the stories of these individuals to a much wider history of violence, and also indicates how such histories operate in a cyclical manner, introducing the potential for the effects of neoliberalism to reverberate back towards their source.

Windust is introduced to the novel through Maxine's investigations into Ice, and initially acts as another locus for her internal conflicts regarding neoliberalism. While she is explicitly critical of his politics, and she initially expresses a sense of disgust towards him, professional interest evolves into physical attraction, and just over half- 
way through the novel she agrees to go to his apartment against her better judgment. After arriving, instead of rejecting his abrupt sexual approach, she willingly submits. The scene is described as follows:

His hands, murderer's hands, are gripping her forcefully by the hips, exactly where it matters, exactly where some demonic set of nerve receptors she has been till now only semi-aware of have waited to be found and used like buttons on a game controller ... impossible to know if it's him moving or if she's doing it herself... (258) ${ }^{34}$

Maxine is unsure as to whether to attribute agency to herself or to the "neoliberal terrorist," and the way that she finds herself engaging in actions that she seems to simultaneously recognize as repulsive may be read allegorically, suggesting how individual subjects might participate in activities they know they ought to reject.

The strength of Maxine's attraction to things that she should disavow is suggested by her admission that she could be tempted to repeat their sexual encounter (260), and when she later receives an out-of-the-blue phone call from Windust, this prompts a dream in which she finds herself entering "a sort of humane mousetrap yet cannot resist the bait, not traditional peanut butter or cheese, but something from the gourmet section, pâté or truffles maybe.” (318) The imagery connects Maxine’s personal attraction to Windust to a wider weakness for the temptations that a market economy has to offer.

However, in addition to highlighting Maxine's own conflicts, the Windust strand

\footnotetext{
34 This seemingly irrational attraction carries echoes of the relationship between Frenesi Gates and Brock Vond in Pynchon's Vineland (1990). Frenesi, an independent filmmaker linked to late sixties radicalism, is powerlessly attracted to the Nixonian/Reaganite agent Vond, whose "erect penis had become the joystick with which, hurtling into the future, she would keep trying to steer among the hazards and obstacles" (293). Thomas Pynchon, Vineland (London: Vintage, 2000).
} 
of the narrative also makes visible the violence done by the U.S. across the Global South to secure neoliberal hegemony. While it is clear that Windust has perpetrated atrocities in the developing world, the details of these are initially hazy and subject to conjecture on Maxine's part. She initially retains the euphemistic language used to justify such actions, her narrative recording that Windust was a specialist in "interrogation enhancement" and "noncompliant-subject relocation" (107). When Maxine then reflects that he has "acquired a portfolio of pain and damage applied to various human body parts that might have added up to hundreds - who knows, maybe thousands - of deaths on his karmic ticket" (109), and that he "can be ticketed with a harvest of innocent souls that puts him easily into the company of more renowned Guinness Book murderers" (244), she begins to acknowledge the extent of his wrongdoing, although the nature of the suffering he has caused still remains rather abstracted in her figuration of it.

Limited though these details are, they connect Windust to a familiar (in part thanks to Naomi Klein's bestselling The Shock Doctrine $[2007]^{35}$ ) if incomplete history of neoliberalism in which Chicago School economic theories attributed to Milton Friedman were tested out and violently implemented in South and Central America in the 1970s, before underpinning domestic and foreign policy in the West from the 1980s onwards. The details of his background noted above accord with Klein's thesis that the advance of neoliberalism has been driven by the introduction of policies via shock or rupture, during "malleable moments, when we are psychologically unmoored and physically uprooted." 36

However, while Klein's history is meticulously researched, her emphasis on

\footnotetext{
35 Naomi Klein, The Shock Doctrine (London: Penguin, 2007).

36 Ibid., 21.
} 
shock and trauma, particularly in the twenty-first century, elides deeper structures of neoliberalism, and it is towards these deeper structures, and their histories, that the stories of Windust and Maxine in Bleeding Edge gesture. ${ }^{37}$ Recent scholarship has grappled with the question of how neoliberalism has become the dominant economic mode, and how that mode has in turn created ideological and behavioral norms from within which this system seems difficult or impossible to critique. One notable example is that offered by Mitchum Huehls and Rachel Greenwald-Smith, who suggest that neoliberalism has progressed through four phases from the 1970 s to the present: "the economic, the political-ideological, the sociocultural, and the ontological." 38 While this four-phase model has been robustly challenged, with other periodizations locating the beginnings of neoliberalism much earlier, ${ }^{39}$ what these narratives have in common is a sense that neoliberalism has evolved from an ideologically-implemented set of economic policies to becoming the social and cultural reality for much of the planet to the extent that it is now a way of being that simply appears natural. This said, those social and cultural realities are very different experiences for people inhabiting different parts of the globe, and it is the relative invisibility of those other worlds that Windust's introduction counteracts.

The history of neoliberalism, and references to deeper structures, are mapped onto Windust through his backstory. Maxine, via an anonymously posted dossier,

\footnotetext{
37 Notably, Anna Hartnell argues that Klein's emphasis "neglects the role of consent" and "fails to track the progression of neoliberal policies as forms of 'slow violence'." However, in Bleeding Edge, the effects on neoliberal policies on the developing world are not so much represented in terms of slow violence as much as they are in terms of outright brutality. Anna Hartnell, After Katrina: Race, Neoliberalism and the End of the American Century (New York: State University of New York Press, 2017), 132.

${ }^{38}$ Mitchum Huehls and Rachel Greenwald-Smith, eds., Neoliberalism and Contemporary Literary Cultures (Baltimore: Johns Hopkins UP, 2017), 8.

39 Alternative narratives are offered, for example, in Sharae Deckard and Stephen Shapiro, World Literature, Neoliberalism and the Culture of Discontent (Basingstoke: Palgrave, 2019); Stephen Shapiro and Liam Kennedy, eds., Neoliberalism and Contemporary American Literature (Dartmouth College Press, 2019) and Slobodian, Globalists.
} 
reads that his "first recorded job, as an entry-level gofer, was Santiago, Chile, on 11 September 1973, spotting for the planes that bombed the presidential palace and killed Salvador Allende" (108). This reference to "the other 9/11" - the CIA-supported coup that installed Augusto Pinochet - is one of the ways the novel binds its interest in turn-of-the-century events and crises with its deeper history of neoliberalism, ${ }^{40}$ exemplifying Quinn Slobodian's argument that the neoliberal project was "not to liberate markets but to encase them, to inoculate capitalism against the threat of democracy." 41

In addition, while Bleeding Edge alludes to this history of violent interventions in South America (1970s) and Central America (1980s), it is also concerned with how Windust himself progressed from spreading the theories and doctrines of neoliberalism driven by "raw ideology" (109) to perpetrating the atrocities to which the novel alludes. In other words, he represents the social and cultural vectors of neoliberalism as much as he does the political, economic or ideological. We learn that he "was one of the founders of a D.C. think tank known as Toward America's New Global Opportunities (TANGO)", and has a "thirty-year history of visiting lecturer gigs, including at the infamous School of the Americas" (109). These details are important as they point to the extent to which neoliberal theories circulated institutionally and culturally, via education, building their challenge to Keynesian or Liberal norms. Windust embodies both the violent establishment of neoliberal policies

\footnotetext{
40 This allusion to the "other 9/11" - the events of which are powerfully portrayed in Ken Loach's contribution to 11 '09'01 (2002), a collection of short films produced by Alain Brigand. This allusion also contributes to the novel's project of de-exceptionalizing 9/11, or as Joseph Darlington has noted, challenging paradigmatic narratives where $9 / 11$ is "severed ideologically from both its causes and its effects." Joseph Darlington, "Capitalist Mysticism and the Historicizing of 9/11 in Thomas Pynchon's Bleeding Edge," Critique: Studies in Contemporary Fiction Volume 57, No 3 (May 2016), 242-253, 242.

41 Slobodian, Globalists, 2.
} 
and the slow and sustained cultural dissemination of neoliberal ideology over decades.

One of the most interesting aspects of Windust's characterization, and the one that addresses the notion of implication, is the sense that he is a corrupted innocent. This conception of Windust is largely created through Maxine's speculations regarding his motivations, although it is later corroborated by details provided by Xiomara. This element of the novel mirrors Graham Greene's 1955 The Quiet American. ${ }^{42}$ In Greene's novel, Alden Pyle, a young American agent (like Windust, his precise affiliation is unclear) arrives in Vietnam in the early 1950s promoting a "third way" beyond either communism or colonialism and influenced by the theories of a fictional author, York Harding. Pyle is full of ideological bluster and exhibits what his cynical interlocuter Fowler registers as a "fanatic gleam." ${ }^{43}$ Moreover, the epithet "innocent" is repeatedly applied to him, although Fowler sees this innocence as dangerous and as a "form of insanity", at one point noting: "innocence is like a dumb leper who has lost his bell, wandering the world, meaning no harm. I never knew a man who had better motives for all the trouble he caused." 44

The Quiet American is the story of how the promotion, in good faith, of abstract theories morphs into complicity with, or perpetration of, atrocity. In the case of Greene's novel, this takes the form of funding ruthless militias and terrorist bombings. Maxine's repeated evocation of innocence in her imaginings of the young Windust echo Greene's novel, notably in descriptions such as when we are told that Maxine can:

Somehow see Windust back then, a clean-looking kid, short hair, chinos and

\footnotetext{
42 Graham Greene, The Quiet American (Middlesex: Penguin, 1955, 1967), p. 15.

43 Ibid., 28.

44 Ibid., 36.
} 
button-down shirts, only has to shave once a week, one of a globe-trotting gang of young smart-asses, piling into cities and towns all over the Third World, filling ancient colonial spaces with office copiers and coffee machines, pulling all-nighters, running off neatly bound plans for the total obliteration of target countries and their replacement by free-market fantasies. (109)

This insistence on Windust's original innocence is reinforced through his relationship with a local woman (again, this mirrors The Quiet American, in which Pyle has a relationship with a Vietnamese woman). Looking back on their romance, Xiomara describes him as a young “entry level kid who didn't know how much trouble his soul was in.” (442)

Rothberg notes the similar etymological roots of implication and complicity, both terms containing the idea of a "folding together" of joint action. In Rothberg's schema, however, complicity is a subcategory of implication, and given that many of Rothberg's examples of implication are inherited relationships with the past predicated on the subject positions of various individuals and groups, complicity may be regarded as a more active form of involvement that involves specific decisions and the exercise of agency. Windust, as this summary of his past indicates, moves rapidly from mere involvement through complicity to full perpetration of atrocity. However, Maxine surmises that "back in that more innocent day, the damage Windust caused, if any, all stayed safely on paper. But then, at some point, somewhere she thinks of as down in the middle of a vast and unforgiving flatland, he took a step. Hardly measurable in that immensity and yet, like finding and clicking on an invisible link on a screen, transported in the act over to his next life." (110) Though she can put together the phases of Windust's career, she is unable to gain a sense of mastery over his internal life, and to identify the point at which innocence shaded into complicity 
and perpetration. A factual history does not, therefore, produce narrative mastery. Maxine's uncertainty with regard to Windust in fact grows as she comes to learn more about him, and her difficulties in reconciling the idea of corrupted innocence with his brutal professional history are so great that she is finally forced to admit that she "can't get the two stories to connect." (244) Maxine's difficulty in reconciling the "two stories" suggests the difficulty of reconciling a way of life in which violence is not generally visible with the knowledge that the same way of life was built upon violent interventions elsewhere.

McHale's reading of Gravity's Rainbow introduces the notion that Pynchon's early narrative mode impelled readers to undertake a number of crossings between the real and hypothetical worlds. However, in Bleeding Edge there is only this world and no other. The experiences of individuals in different parts of the world vary so greatly, though, that they are unable genuinely to see and understand those outside their immediate field of vision. For this reason these separate populations, to all intents and purposes, inhabit alternative worlds. In other words, Maxine's struggles to understand Windust mirror her difficulties in recognizing her own implication in the violent effects of neoliberalism, and only her encounter with a direct perpetrator of such violence allows this relationship to become visible. The intersection of process and rupture, then, as embodied by the encounters between Maxine and Windust, is what makes visible to Maxine her implication in the violence perpetrated upon these other worlds.

Moreover, in addition to emphasizing specific elements of Windust's character, the way that Bleeding Edge evokes intertexts represents a search for periodicity, defined by Deckard and Shapiro as the attempt to "ascertain the nature of recurring 
familiarities across historical cycles of capital's expanded reproduction."45 The clear echoes of The Quiet American suggest a cyclical repetition of patterns in American interventions in Indochina in the 1950s and in South America in the 1970s. Initially, the details of Windust's past suggest that these cycles are a matter of repeated U.S. behavior towards the developing world; however, as we discuss below, the $9 / 11$ attacks introduce a new form of cyclicity in which these historical wrongs begin to rebound on the source of their perpetration.

\section{Points of Intersection}

In The Crying of Lot 49, Oedipa is introduced to a device called Maxwell's Demon. It is supposed to work by exchanging information for energy without a resulting gain in entropy, thus creating perpetual motion. As its owner, John Nefastis, explains: "entropy is a figure of speech ... it connects the world of thermodynamics with the world of information flow. The Demon makes the metaphor not only verbally graceful, but also objectively true." ${ }^{46}$ At this moment, then, the immaterial world of language and the material world of energy intersect. However, as Frank Palmeri points out, Maxwell's Demon was based on an incomplete understanding of information flow that had been rectified by the time that Pynchon wrote Lot 49, and scientists would have been aware of this by the time that Nefastis shows the Demon to Oedipa ${ }^{47}$ Moreover, within the diegetic world of the novel, the Demon simply does

\footnotetext{
45 Deckard and Shapiro, World Literature, Neoliberalism and the Culture of Discontent, 27.

46 Pynchon, The Crying of Lot 49, p. 85. Pynchon's questioning of causality can be regarded as a career-long interest, evident for example in Gravity's Rainbow when Leni Pökler raises the notion that relationships may be "parallel, not series.” Thomas Pynchon, Gravity's Rainbow (New York: Viking Press, 1973), 159.

47 Frank Palmeri, "Neither Literally nor as Metaphor: Pynchon's The Crying of Lot 49 and the Structure of Scientific Revolutions," ELH Volume 54 No 4 (Winter 1987), 979-999, 981-82.
} 
not work, and the Second Law of Thermodynamics holds firm.

In Bleeding Edge, a similar moment of intersection occurs in the days following 9/11, when Maxine and Horst discuss his uncanny ability to read the markets, and she suggests that the same intuition may have kept him away from the twin towers on the morning of the attack. The exchange begins with Horst puzzling over his own knack:

“It wasn't me that ever knew anything. But something did. Sudden couple extra lines of brain code, who knows. I just followed along."

"But then... if it was the same weird talent that kept you safe..."

"How could it be? How could predicting market behavior be the same as predicting a terrible disaster?"

"If the two were different forms of the same thing."

"Way too anticapitalist for me, babe." (320)

This passage posits the same question as Maxwell's Demon, asking whether two apparently unconnected phenomena, one from the world of information, and one from a separate, material reality, might not only parallel each other in a way that is "verbally graceful" but also might in fact be "objectively true."

Yet in the wake of $9 / 11$ the stakes are higher and broader. In place of the thought experiment represented by Maxwell's Demon in Lot 49, the question of a convergence of apparently disparate spheres of activity in Bleeding Edge has implications for understanding the terrorist attacks, and for understanding the flows of capital and power out of which the motivation for the attacks may have grown. In fact, even prior to this exchange between Maxine and Horst, the novel repeatedly suggests that market behaviors, geopolitical power, and the consequences for people "on the ground" are 
connected.

In the light of the $9 / 11$ attacks, transactions that sit on the edge or outside of legal mechanisms of exchange - such as those discussed above, in the section on process take on a new significance, particularly when they involve the Middle East. At one point before 9/11, Maxine describes how money is routed through a hawala arrangement, an informal network of trusted ties that allows users to circumvent money-handling fees, that involves shipments of 'halvah, pistachios, geranium essence, chickpeas, several kinds of ras el hanout, and shipments outbound of mobile telephones, MP3 players, and other light electronics, DVDs, old Baywatch episodes in particular...' (261) At this point, these commodities seem relatively harmless, further examples of how those at the fringes attempt to gain some leverage on the system; but when it later emerges that one of the stinger missile launchers in the videos anonymously sent to Maxine bears Pashto writing on the battery cap, this suggests that violence perpetrated elsewhere may return and rebound on the developed nations that had previously thought themselves secure - a potential that becomes reality on September $11^{\text {th }}$. The sense that finance, information, and the brute violence of the attacks are shown to be entangled, mean Maxine's earlier comment that she "can't get the two stories to connect" (244) takes on a new significance at the point when the two stories - one of immaterial labor and exchange, one of material suffering - are forced together by $9 / 11$.

In Multidirectional Memory, Rothberg shows how the events of the past do not necessarily impact on the present in a linear way, but are "subject to ongoing negotiation, cross-referencing, and borrowing." 48 Rothberg's focus here is primarily

48 Rothberg, Multidirectional Memory, 3. 
on the rhetorical uses of memory, his central concern being "what kinds of aesthetic form are adequate to the task of representing and recalling history's overlapping forms of violence." 49 One such form that he discusses is the choc en retour, addressed through the work of Aimé Césaire, and translatable as "reverse shock, backlash, or boomerang effect" (70). Rothberg argues that, for Césaire, "the European subject is necessarily blind to the social production of his or her own well-being" 50 and that "his concept of the choc en retour is meant to force an encounter between European and colonial histories in such a way that it becomes impossible for Europe to remain blind to its agency in the world."51 Multidirectional Memory predates Rothberg's work on implication, but in this comment it can be seen how the earlier book sets the stage for his arguments about the relationship between blindness and implication in the latter.

Rothberg's discussion of European imperialism parallels our argument here regarding U.S.-led neoliberalism, and in Bleeding Edge, the violent reverberations of the economic system mean that it becomes difficult after $9 / 11$ for the U.S. to remain blind to its implication in suffering elsewhere. If Maxine's encounters with Windust lead her into a growing awareness of the violence perpetrated in the name of neoliberal ideology, the novel suggests that $9 / 11$ is a choc en retour that causes the inhabitants of New York to actually experience the reverberations of such violence. This is suggested by Shawn when he argues that U.S. prosperity depends on suffering elsewhere, and structural blindness towards that suffering, with the population of the developed world “never caring about who's paying for it, who's starving somewhere else all jammed together so we can have cheap food, a house, a yard in the burbs";

\footnotetext{
49 Ibid., 35.

50 Ibid., 81-82.

51 Ibid., 81 .
} 
and as he notes, "the payback keeps gathering" (340). This payback is shown in vivid and material terms, notably through imagery representing U.S. citizens as refugees following the $9 / 11$ attacks, as "legions of traumatized souls coming across the bridge, dust-covered, smelling like demolition and smoke and death, vacant-eyed, in flight, in shock. While the terminal plume ascended." (445)

If passages such as this suggest a growing awareness of implication on the part of the characters, this awareness does not necessarily produce forms of action that might remedy the wrongs perpetrated in the name of the neoliberal project. ${ }^{52}$ As noted above, in the schema of the novel, the Gabriel Ice narrative mainly deals with processes of immaterial exchange within the comfortable environment of the developed world, while Windust's backstory introduces violence, rupture and material suffering taking place elsewhere. In the final section of the novel, though, Maxine experiences neoliberalism both as rupture and ongoing process simultaneously, as the aftermath of the attacks unfold while the markets recover and while the internet continues to evolve. She is, therefore, finally presented with this dual perspective, but instead of providing any sort of enlightening revelation, the effects are instead disorienting.

The disorientation caused by the intersection of the material and immaterial spheres is explored in depth though the nature and effects of the internet. Late in the novel, Maxine begins to suffer from what she calls "virtuality creep", (431) and comments that "she's finding it hard to tell 'real' NYC from translations like Zigotisopolis", the virtual city jointly created by her children, Ziggy and Otis (429).

\footnotetext{
52 In fact, as Greg Grandin notes, the rupture of 9/11 was actually exploited by the Bush administration, which harnessed "the force of American revanchism" to further deregulation in the U.S. and abroad, in the aftermath of the attacks. Greg Grandin, Empire's Workshop: Latin America, the United States, and the Rise of the New Imperialism (New York: Owl Books, 2007), 197.
} 
The intersections between the material and immaterial realms, and their role in both strands of the novel is most clearly suggested in a conversation between Maxine and the Russian enforcers Misha and Grisha about DeepArcher, the deep web virtual reality platform created by her friends Justin and Lucas, and coveted by the novel's antagonists. Maxine, anticipating an outraged response, suggests that DeepArcher is “only, like, code?" to which one of the two responds, "with what could be either naïve faith or raving insanity, 'it's real place!'” (373). That the question of whether DeepArcher can be considered as "real" or not may actually be based on the wrong paradigm for understanding the situation in which Maxine finds herself, is later suggested by Grisha when he refers to the murder of Lester Traipse, which initially drew Maxine into her involvements with Ice and Windust:

"Lester," Grisha whispers, eyes angling upwards toward the pool, "Lester's soul. You understand? Stingers on the roof. That." A head gesture out into the All Saints night, towards far downtown where the Trade Center used to stand, past the invisible swarming hundreds of thousands of masked celebrants in streets lighted and semi-lit, out into the reeking hole with the Cold War name at the lower edge of the island. (373)

Maxine cannot hope to "understand" Lester's death, either in terms of its cause, or in terms of "what it means." Grisha's vague gesture into the night, however, suggests that the myriad connections in which they are embroiled are the sum and irreducible total by which Lester's death may be understood. It cannot be evoked by simple reference, but through an awareness of the structures in which these characters are implicated.

The nebulous sense of implication evoked by Grisha's comments, and 
experienced by Maxine throughout most of the novel, is replaced by a more concrete sense of situatedness following the death of Windust and as the collapse of any distinction between the material and immaterial spheres gathers pace. This collapse is not just explored through the internet and its blurring of the virtual and the real, but is also enacted in the way that the figurative direction of language is reversed, with language from the virtual world, itself originally taken from physical objects, is eventually in turn used to describe material phenomena. As Siegel notes, the novel contains numerous examples of such chremamorphic sequences, i.e. those that depict humans in language usually employed to describe objects, and he argues that these "reveal that we are all already cyborgs, that meatspace is cyberspace, and that our posthuman ontology leaves us increasingly susceptible to and complicit in the domination of the corporations, governments, and law enforcement agencies of late capitalism." 53 On this basis, he proceeds to argue that "readers follow Maxine as she traces the interconnections among the government, capital, law enforcement, and the posthuman citizens who populate the novel's amalgam of meatspace and cyberspace, and in the process, they are enlightened along with Maxine."54

While we agree that the novel's points of intersection reveal the multitude of connections between the various spheres noted by Siegel, we question whether Maxine arrives at the end of the novel "enlightened." There are certainly moments suggestive of revelations, such as when she goes back into DeepArcher, and finding herself lost, she ends up "toggling between horizontal and overhead views", discovering a "way to vary the angle in between, so that like an archaeologist at dawn she can now see the desert at a very shallow raking angle, allowing her to pick up

53 Siegel, "Meatspace is Cyberspace," 13.

54 Siegel, "Meatspace is Cyberspace," 25. 
relief features that would otherwise be invisible." (403-04)

It is tempting to read this as a figurative comment on the way that intersections between the real and the virtual reveal that which was previously hidden, and in fact this passage does more than simply reveal these connections because it also shows how the virtual world now informs Maxine's behavior in a concrete way: these links lead her back to Windust - or at least to his avatar, who appears as "a younger version of himself, a not-yet-corrupted entry-level wise-ass, brighter than he deserves." (406) Yet uncertainties continue to proliferate at these points of intersection and, having accepted Windust's less-than-gracious invitation to his apartment (he "can't guarantee an erection" 406), Maxine re-emerges from DeepArcher, hails a taxi, and arrives to find him already dead (at which point the avatar's inability to achieve tumescence takes on a darker humor).

As a result, she realizes that Windust must have been murdered before her conversation with his avatar and the digital form that she encounters does not, therefore, represent the "real" Windust. Maxine is therefore left speculating as to whether "he was speaking to her from the other side or it was an imposter and the link could have been embedded by anybody, not necessarily a well-wisher, spooks, Gabriel Ice..." (411) Again, then, Maxine is unable to achieve mastery of this narrative (of Windust's death) and the points of intersection between the virtual and the real reveal that a signifier in the former world no longer finds its referent in the latter.

Maxine's solution to the uncertainty engendered by these points of intersection, and more generally by her sense of implication in larger events, initially appears to be a retreat into domesticity. She overcomes the "epistemological bug" of "virtuality creep" (433) largely by re-grounding herself in the domestic sphere, enabled in part 
by re-establishing her relationship with Horst. Indeed, when her children begin to question whether the things they encounter and experience are real or not, Horst answers promptly and without equivocation. For this reason, Maxine refers to him as a "calibration standard of last resort" (433), and he thus represents a retreat into a sort of locally-sited, common sense empiricism.

Yet there is something more complex, and more tentatively optimistic, going on here than a surrender to the idea that the "ol' Wall Street stupidity" (48) represented by Horst is the best basis for understanding the world. The final few sections of the novel show how Maxine recalibrates her perspective so as to see the reverberations of neoliberal violence as the inevitable results of a system in which she is implicated, and with which she must eventually reckon. This process is nowhere better illustrated than through her late encounter with Xiomara, their meeting illustrating in microcosm the process of broadening awareness of implication that the "forced encounter" of 9/11 begins to produce. The chapter begins on the subway, with Maxine observing faces on parallel trains that remain anonymous to her, but that she refers to as "the day's messengers from whatever the Beyond has for a Third World, where the days are assembled one by one under non-union conditions." (439) Maxine's gaze at this point does not differ substantially from the beginning of the novel in that she momentarily acknowledges the possible suffering caused by neoliberalism at the periphery of her vision and experiences, but lacks the desire or critical awareness to probe further. However, in this instance, an individual emerges from Maxine's abstraction via "a slow zoom onto one particular window of the other train, one face in this window, too clearly meant to invite Maxine's attention." (440) The face-to-face meeting with Xiomara that follows forces Maxine to recognize her own preconceptions: she “can't say what she might've been expecting - braids, silver 
jewelry, long skirts, bare feet," but the woman who she meets is a "polished international beauty in a power suit" (441). Xiomara is, in one sense, the product of precisely the type of neoliberal interventions effected by Windust, and at this point the late-adopting periphery returns to the now-corrupted core.

While Windust, his work now done, has been disposed of in a violent and ruthless manner by those who once used his skills, Xiomara's appearance acts as a non-violent choc en retour, and one that offers the possibility of compromise and community rather than a continuing cycle of violence. As the women have breakfast together, Xiomara supplements Maxine's previous suppositions about Windust's past with her own details, thus affirming the brutality about which she hitherto speculated. Xiomara's complicity with Windust's violence is also revealed in this passage, albeit focalized through Maxine. Again, free indirect discourse sliding into interiority is used, but this time with the self-questioning partially transferred onto Xiomara: "still inside the perimeter of newlywed bliss, he sneaks out of bed, does what he's in Guatemala to do, slips back, in the worst hours of the morning, nestling his cock against the crack of her ass, how could she not have known?" (443-4) In one sense, this looks like a transference of guilt and blame away from the developed world and onto an individual from the developing world whose options were much more limited. At the same time, though, it represents a broadening of vision and effort at empathy on Maxine's part that was hitherto absent, but is here prompted by her encounter with a figure arriving at the metropolitan center from the developing world.

The chapter concludes with the two walking to Ground Zero together to bear witness to the aftermath of the choc en retour that struck at the financial heart of the U.S., and, it might be argued, the heart of the neoliberal project. They offer different interpretations of the site, with Maxine noting that the World Trade Center never had 
the iconic resonance of the Statue of Liberty before internally evoking DeepArcher as a space where the destroyed building might somehow be virtually reconstructed, and with Xiomara evoking her own conception of Hell. The point of convergence of their attempts at comprehension, though, is Windust. In other words, the figure who represents and embodies a violent history of neoliberalism is also the figure through whom two individuals, one a beneficiary from the developed world and one an initially-complicit subject from the developing world, attempt to make sense of the attacks. Recognition of the effects of neoliberalism, both as process and as rupture, thus arrives through an understanding of their relationship and of how each is implicated in the other's history.

While the meeting between Maxine and Xiomara situates individuals as being implicated in world-historical events, themselves the products of neoliberalism, the novel ends with two local and domestic scenes. These have the effect of reemphasizing the limitations of any individual's vision, and indeed of any individual's ability to construct a narrative that encompasses their implication in wider systems; yet by the end of the novel, these limitations are no longer mere blindness to the relationship between local actions and global effects, but instead gesture towards the difficulty of fully understanding one's implication in world-encompassing systems. In the first of these encounters, boundary crossings between the material and immaterial spheres are emphasized and materialized in almost comic fashion, when Maxine and March attempt to dissuade Ice from pursuing his estranged wife, March's daughter Tallis. As the two discuss the precautions they need to take, March states:

"Lend me your handgun." Beat. "Just kidding."

"Yet another license pulled. Would be the thing..." 
“Only a metaphor.” (449)

Yet when the two confront Ice, Maxine does in fact threaten him with her Beretta. At this point, Ice seems unable to accept his own lack of mastery over the narrative, stating “it doesn't happen ... I don't die. There's no scenario where I die.” (473) Ice therefore still occupies the position similar to the more privileged sections of $\mathrm{New}$ York prior to $9 / 11$, blind to the possibility of a violent material reality puncturing his world of comfort and immaterial labor. Ice's internal narrative is, however, shown to be weaker than the brute fact of the gun in Maxine's hand, the idea that something can remain "only a metaphor" is shown to be false and, in some cases at least, it is shown that wrongdoing can be confronted locally.

The novel's final encounter takes place immediately afterwards, when Maxine returns home just in time to catch her children preparing to leave for school. Although the sense of groundedness provided by Horst appears to be comforting to Maxine, this apparent stability is shown to be illusory due to the combination of Horst's Homer Simpson-like qualities ${ }^{55}$ and, more importantly, the way that the 9/11 attacks (during which Horst was absent from home) overwhelmed any capacity for individual action. Moreover, prior to this section of the narrative, the fact that Maxine cannot control what happens to those within even her narrow domestic sphere is revealed by the attempt to kidnap Ziggy and Otis. Horst attributes this attempt to a "standard New York creep.” (415) Maxine, in contrast, thinking of the undisclosed dangers represented by Ice and Windust, states that "there are a thousand things in this town to be afraid of, maybe even two thousand, and there's too much else he won't likely ever know." (415) For this reason, her awareness that she is implicated in narratives that

\footnotetext{
${ }^{55}$ See Jeffrey Severs, “'Homer is my role model': Father-Schlemiels, Sentimental Families, and Pynchon's Affinities with The Simpsons," in Ali Chetwynd, Joanna Freer and Georgios Maragos, eds., Thomas Pynchon, Sex and Gender (Athens, GA: The University of Georgia Press, 2018), 194-208.
} 
are shaping events in ways they cannot control means that she does not allow herself to sit comfortably in an illusion of domestic security.

The novel's ending reiterates this lack of control. Maxine offers to walk Ziggy and Otis to school, but Ziggy confidently prepares to set off without her, stating "It's all right, Mom. We're good." (477) Maxine is only able to watch her boys as far as the elevator as they begin their journey. Again, Maxine's actions are a microcosm of the wider situation: her immediate field of vision only extends so far, and unseen threats exist beyond. She has, by this point, recognized that a life apparently unthreatened by violence or material hardship is an illusion produced by her own blindness towards other worlds in which she now realizes she is implicated. This recognition is suggested by Maxine's response: "I know you are, Zig, that's the trouble."

\section{Conclusion}

Although Bleeding Edge concludes with a restoration of order after its various ruptures, the novel does not offer closure and meaning through domesticity. Instead, a story of rupture and violence has entered into one of continuity and security.

Chetwynd, following McHale, argues that Pynchon's aesthetics, up to Against the Day, rely on crossings between the real world and alternative possible worlds within the narrative, and that these ask the question of "what would historical existence and historical agency have to be, metaphysically, to reverse the seeming fait accompli of the post-Enlightenment identification of capitalism with reality?" (453). In Bleeding Edge, there are no alternative worlds, only this one, in which capitalism is reality. That reality, however, looks very different depending on where one is situated: it is a largely comfortable experience of immaterial exchange for those in Manhattan while 
it is an experience of rupture and violence for many in the developing world. Bleeding Edge forces an encounter, then, between these two worlds, and does so to impel a recognition of implication in the system that produces this disjunction and inequality.

When Xiomara and Maxine stand at Ground Zero, and the latter describes it as "never a Beloved American Landmark" but as "pure geometry", and she internally adds that:

I know of a place [...] where you dowse across an empty screen, clicking on tiny invisible links, and there's something waiting out there, latent, maybe it's geometric, maybe begging like geometry to be contradicted in some equally terrible way, maybe a sacred city all in pixels waiting to be reassembled, as if disasters could be run in reverse, the towers rise out of the black ruin, the bits and pieces and lives, no matter how finely vaporized, become whole again. (446)

The sense of connectedness and pervasion, earlier rendered as thrilling during Maxine's visit to Saks, has by this point been replaced here by a sense of threat. Yet despite this tone, there is another way of reading this image, and it is possible to interpret the "latency" of which she speaks in a tentatively positive light, that is, in terms of a recognition of implication, and the sense of precarity that this recognition induces. The material reality of the attacks cannot be "contradicted", and Maxine is unable to construct a narrative that traces the innumerable relationships between neoliberalism as process and this singular event; but by paying attention to the connections that it reveals, a fresh relationship with the neoliberal reality can be configured. Bleeding Edge is not an optimistic novel, but neither is it resigned to an acceptance of twenty-first century norms. It begins to identify forms of vision that circumvent neoliberalism's hegemony and this search begins with a recognition of our 
implication in that system. 